\title{
A brief review on Triazole and its Pharmacological Application
}

\author{
Kuldeep T. Padhyar ${ }^{1}$, Rajendra S. Patil ${ }^{2}$, Navanand B. Wadwale ${ }^{3}$ \\ ${ }^{1,2,3}$ PG Dept. of Chemistry, MGVs Maharaja Sayajirao Gayakwad College Malegaon Camp Malegaon \\ Dist. Nashik MS-423105, India
}

\begin{abstract}
The triazole core is one of the most imperative and well known heterocycles which is composed of nitrogen atom which forms natural products with medicinal claims. Triazole moiety is present as a principal structural component in the drug categories such as antimicrobial, anti-inflammatory, analgesic, antineoplastic, antimalarial, antiviral, antihypertensive, local anaesthetic, antianxiety, anti-Parkinson's, antidepressant, antioxidant, antihistaminic, antitubercular, antidiabetic etc. The broad and potent activity of triazole and their derivatives has established them as pharmacologically significant platforms. The elementary heterocyclic rings present in the numerous medicinal mediators are 1,2,3-triazole and 1,2,4-triazole. A huge capacity of investigations has been approved on triazole and their results, which has proved the pharmacological status of this heterocyclic core. The current paper is an try to review the pharmacological activities reported for triazole derivatives in the current literature with an apprise of current research discoveries on this nuclei.
\end{abstract}

KEYWORDS: 1,2,3-Triazole, 1,2,4-Triazole, Antitubercular, Antimalarial, Antimicrobial, Antiviral Such Activity.

\section{INTRODUCTION}

Triazole is acknowledged as pyrrodiazole is single class of organic heterocyclic complexes containing a five-membered Di unsaturated ring assembly composed of three $\mathrm{N}$ atoms and two $\mathrm{C}$ atoms at non-adjacent positions. The modest form of the triazole domestic is triazole itself. Triazole is a white to pale yellow crystalline solid with a weak, distinctive odour, it is resolvable in water and alcohols. It melts at $120^{\circ} \mathrm{C}$ and boils at $260^{\circ} \mathrm{C}$. It occurs as a pair of isomeric chemical composites as $1,2,3$ - triazole and $1,2,4-$ triazole with molecular formula $\mathrm{C}_{2} \mathrm{H}_{3} \mathrm{~N}_{3}$, and a molecular weight of 69.06[1]. There are two isomers are,
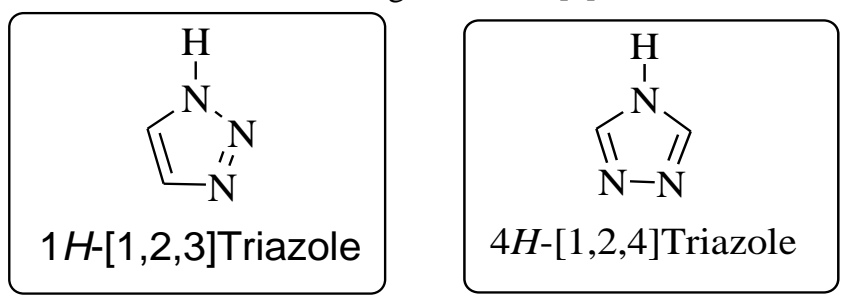

Kesavan Karthikeyan et al [2] reported the synthesized compound shows potent anti-fungal activity against the Candida albicans and Aspergillus niger pathogen.

Xuezhen Zhu et al [3] the group of scientist work describes the syntheses of diverse triazole bridged flavonoid dimers and identifies potent, nontoxic, and highly selective Breast Cancer Resistance Protein (BCRP) inhibitors.

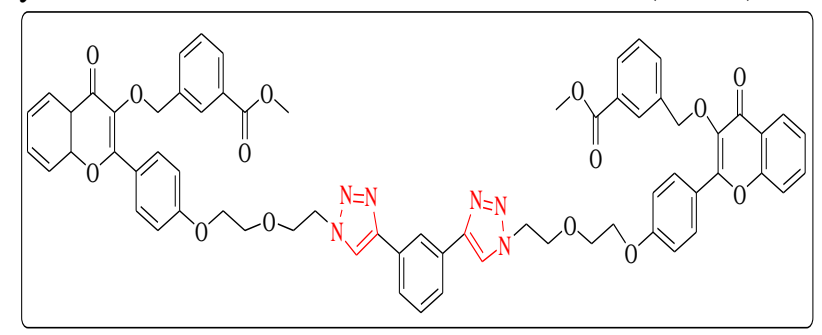

Jian-Wei Zhao et al [4] current work describes anti-gastric cancer activity evaluation of novel triazole nucleobase analogues containing steroidal/coumarin/quinoline moieties 


\section{International Journal of Current Science Research and Review}

ISSN: 2581-8341

Volume 05 Issue 01 January 2022

DOI: 10.47191/ijesrr/V5-i1-25, Impact Factor: 5.825

IJCSRR@ 2022

Www.ijjcsrr.org
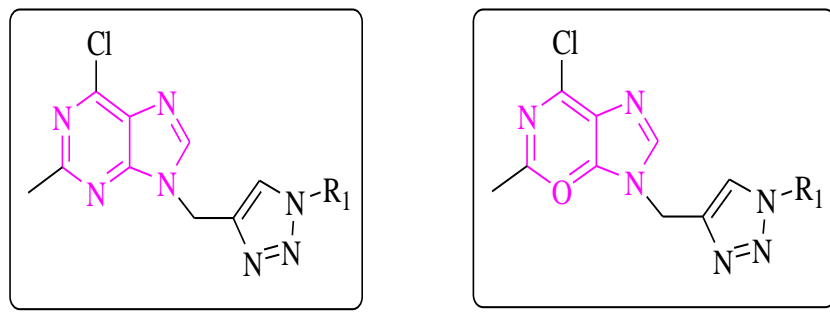

Zhe Zhang et al [5] present work describes synthesis and biological activities of novel pleuromutilin derivatives with a substituted triazole moiety as potent antibacterial agents. A series of novel pleuromutilin derivatives possessing 1,2,3-triazole moieties were synthesized via click reactions under mild conditions. The in vitro antibacterial activities of these derivatives against 4 strains of S. aureus (MRSA ATCC 43300, ATCC 29213, AD 3, and 144) and 1 strain of E. coli (ATCC 25922) were tested by the broth dilution method.

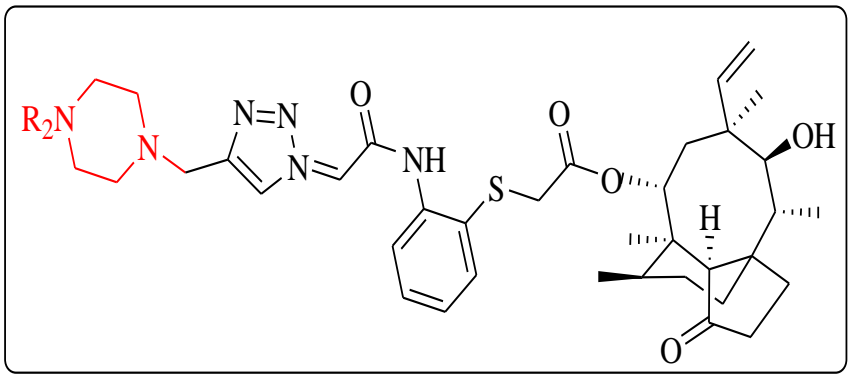

Nashwa Hafez Zaher et al [6] existing work describes synthesis and molecular docking of novel triazole derivatives as potential $\mathrm{CoV}$ helicase inhibitors. Current investigation of anti-MERS-CoV activity of newly synthesized sixteen halogenated triazole compounds through the inhibition of helicase activity using the FRET assay. All new compounds underwent justification for their target structures via microanalytical and spectral data. SAR studies were performed and molecular docking done to check the activity.

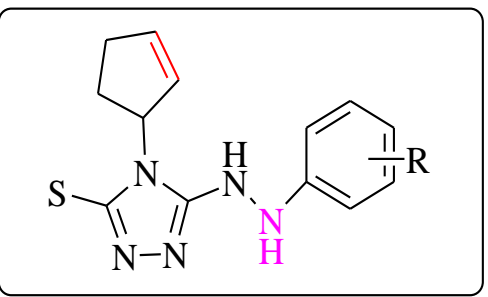

Satish K. Awasthi et al [7] present work describes Insights into the interaction of potent antimicrobial chalcone triazole analogues with human serum albumin.

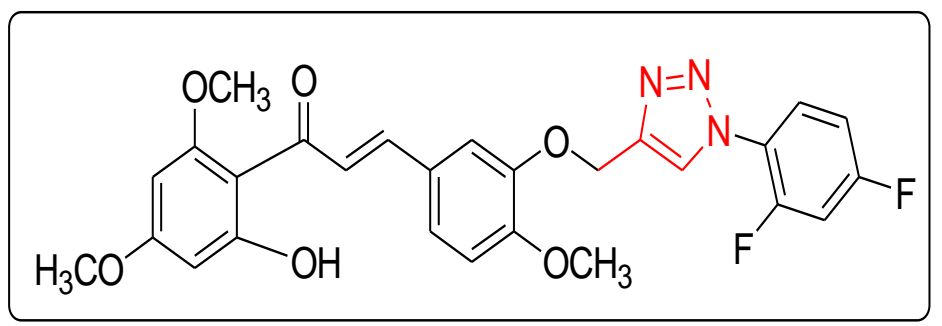

Nguyen D. Thanh et al [8] present work describes Efficient click chemistry towards novel 1H-1,2,3-triazole-tethered 4-H chromene D-glucose conjugates: Design, synthesis and evaluation of in vitro antibacterial, MRSA and antifungal activitie 


\section{International Journal of Current Science Research and Review}

ISSN: 2581-8341

Volume 05 Issue 01 January 2022

DOI: 10.47191/ijesrr/V5-i1-25, Impact Factor: 5.825

IJCSRR@ 2022

www.ijcsrr.org
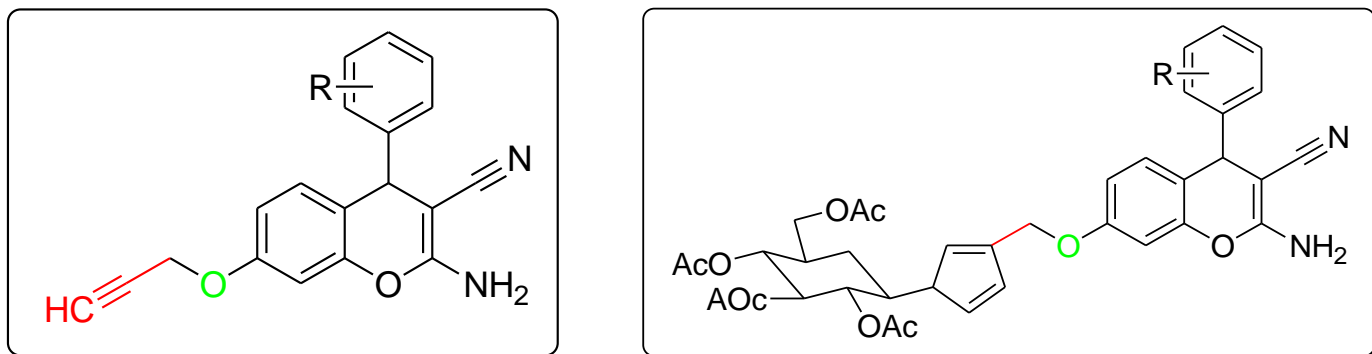

Kesavan Karthikeyan et al [9] the group of co-workers Synthesize the1,2,3-triazole tethered 3-hydroxy-2-oxindoles: which is used as corrosion inhibitors for steel in acidic medium and their compound shows potent anti-microbial activity.

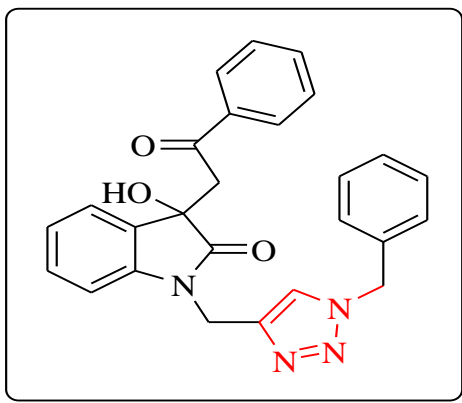

Nerella Sridhar Goud et al [10] reported the Novel benzimidazole-triazole hybrids as apoptosis inducing agents in lung cancer. They design and synthesis, 18 F-radiolabeling \& galectin-1 inhibition studies.<smiles>Oc1cccc(-n2cc(COc3ccc(-c4nc5cc(Cl)ccc5n4Cc4ccccc4)cc3)nn2)c1</smiles>

Gowravaram Sabitha et al [11] reported the Synthesis of 1H-pyrrolo[2,3-d] pyrimidine-1,2,3-triazole derivatives. Which studies the potent anti-tubercular agents.

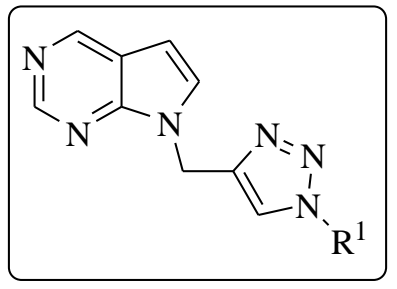

Arezoo Rastegari et al [12] have reported to design and synthesis of novel 1,2,3 triazole chromenone carboxamide derivatives which shows potent anti-Alzheimer's activity.

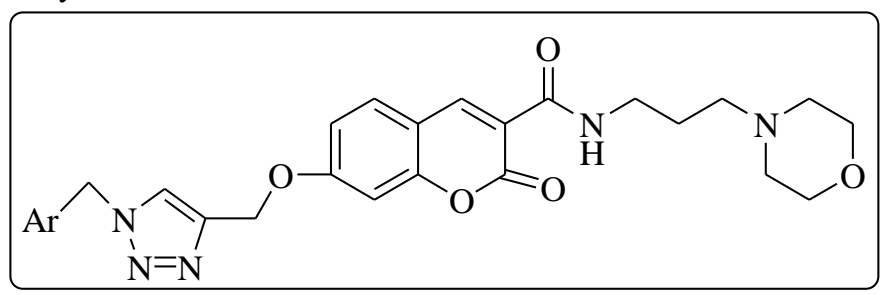




\section{International Journal of Current Science Research and Review}

ISSN: 2581-8341

Volume 05 Issue 01 January 2022

DOI: 10.47191/ijesrr/V5-i1-25, Impact Factor: 5.825

IJCSRR@ 2022

www.ijjcsrr.org

Jurupula Ramprasad et al [13] have developed the novel Synthesis of quinoline-triazole analogs for antitubercular properties via molecular hybridization approach.

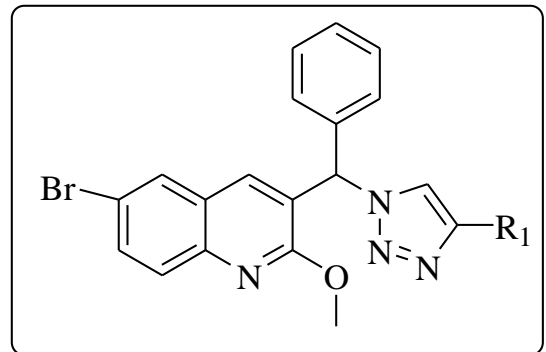

Shaker A. Mousa et al [14] a group of scientists developed Triazole modified tetraiodothyro acetic acid conjugated to Polyethylene Glycol. Which shows high affinity thyrointegrin $\alpha \mathrm{v} \beta 3$ Antagonist with Potent Anticancer Activities in Glioblastoma Multiforme.

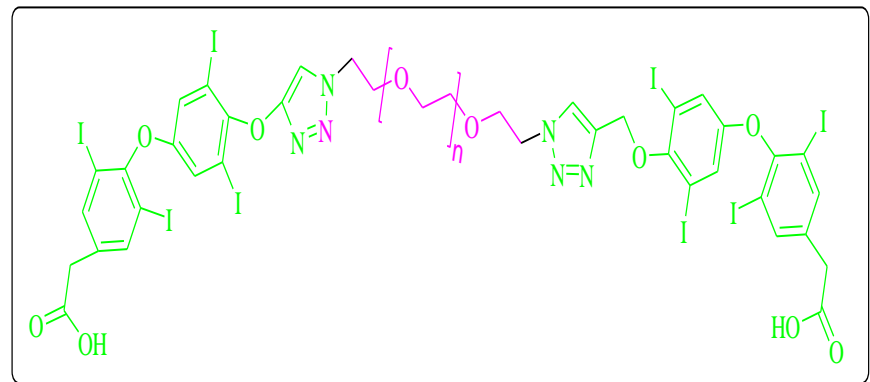

Thayane M. Queiroz et al [15] have study the Semi-synthesis of $\beta$-keto-1,2,3-triazole derivatives from ethinylestradiol and the synthesized compound shows cytotoxic activity.

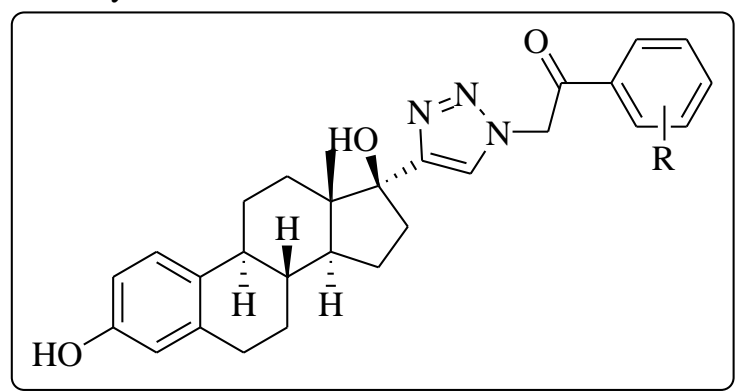

Renjith Raveendran Pillai et al [16] have Synthesize schiff bases tethered 1,2,4-triazole and pyrazole rings and spectroscopic characterization, to study DFT calculations, molecular dynamics simulations and biological evaluation compound.

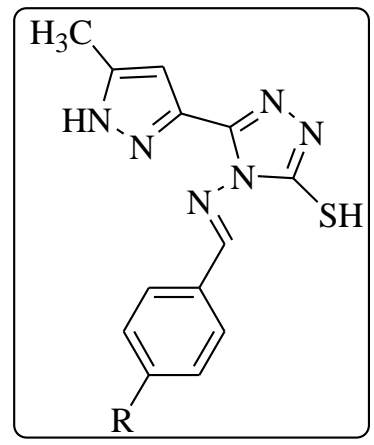

Zahra Najafi et al [17] they developed the novel tacrine-coumarin hybrids linked 1,2,3-triazole compounds which shows as antiAlzheimer's activity. In vitro and in vivo biological evaluation of compound and also study docking. 


\section{International Journal of Current Science Research and Review}

ISSN: 2581-8341

Volume 05 Issue 01 January 2022

DOI: 10.47191/ijesrr/V5-i1-25, Impact Factor: 5.825

IJCSRR@ 2022

www.ijcsrr.org

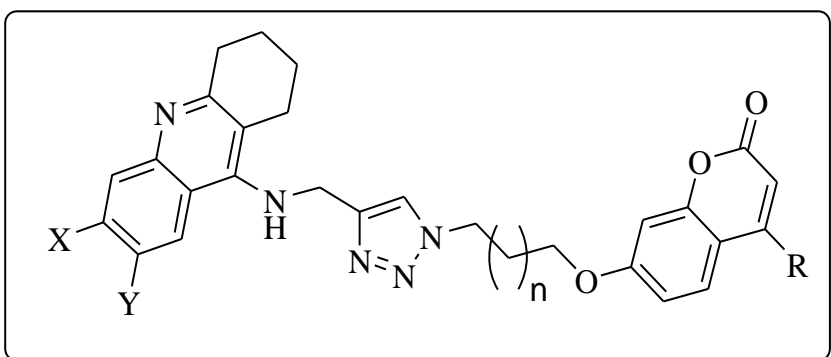

Muhamad Mustafa et al [18] have synthesized a potent combretastatin A-4 analogs containing 1,2,4-triazole which carried out antiproliferative, anti-tubulin activity, and docking study.<smiles>[R]c1ccc(-n2nc(C(=O)Nc3cc([R2])c([R3])c([R1])c3[R3])nc2-c2cc(OC)c(OC)c(OC)c2)cc1Cl</smiles>

Ana I Matesanz et al [19] New Pt (II) have developed the triazole thiosemicarbazone' complexes. And analyse their reactivity and potential antitumoral activity.

Guo-qing Lu et al [20]] reported the Design, synthesis and biological evaluation of novel uracil derivative bearing 1, 2, 3-triazole moiety as thymidylate synthase (TS) inhibitors and as potential antitumor drugs.<smiles>O=c1[nH]cc(S(=O)(=O)Nc2ccc(-c3cn(-c4ccccc4)nn3)cc2)c(=O)[nH]1</smiles>

Shuai Li et al [21] ] reported the Design, synthesis and biological evaluation of erythrina derivatives bearing a 1,2,3-triazole moiety as PARP1 inhibitors.
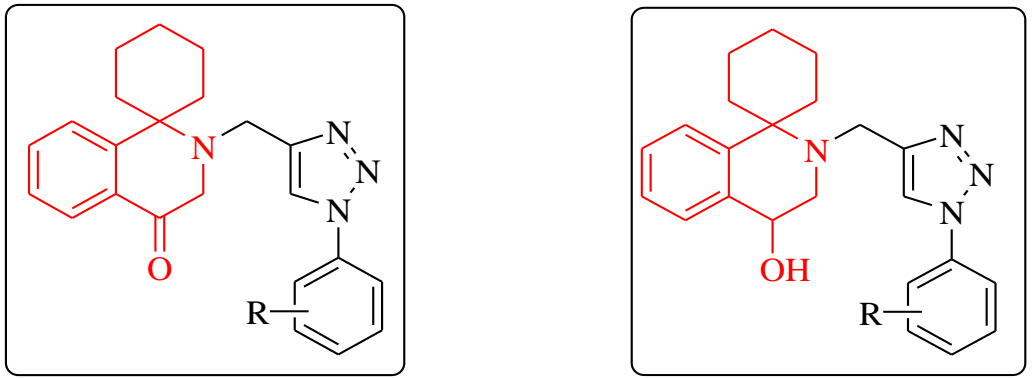

Kashmiri Lal et al [22] study the Design, synthesis, antimicrobial evaluation and docking studies of urea-triazole-amide hybrids

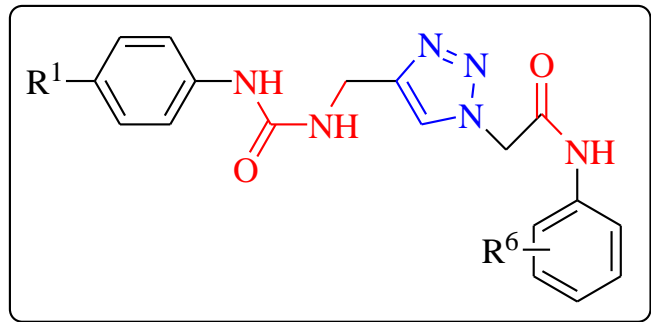




\section{International Journal of Current Science Research and Review}

ISSN: 2581-8341

Volume 05 Issue 01 January 2022

DOI: 10.47191/ijesrr/V5-i1-25, Impact Factor: 5.825

IJCSRR@ 2022

www.ijcsrr.org

Amandeep Kaur et al [23] Multifunctional Mono-Triazole Derivatives Inhibit A $\beta 42$ Aggregation and Cu2+-Mediated A $\beta 42$ Aggregation and Protect Against A $\beta 42-$ Induced Cytotoxicity.

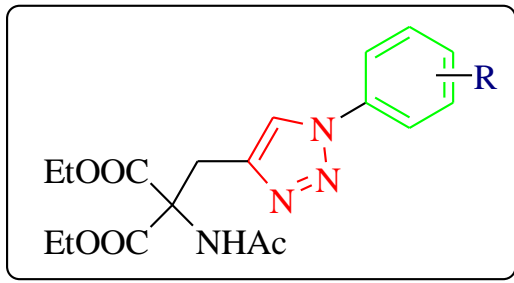

Oleksandr Grytsai et al [24] Synthesis and biological evaluation of 3-amino-1,2,4-triazole derivatives as potential anticancer compounds.

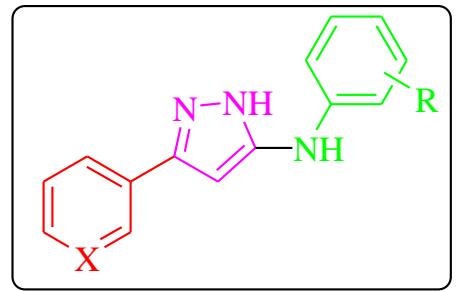

Mehmet Çiftçi et al [25] In vitro cytotoxic and in vivo antitumoral activities of some aminomethyl derivatives of 2,4-dihydro-3H1,2, 4-triazole-3-thiones_Evaluation of their acetylcholinesterase and carbonic anhydrase enzymes inhibition profiles.

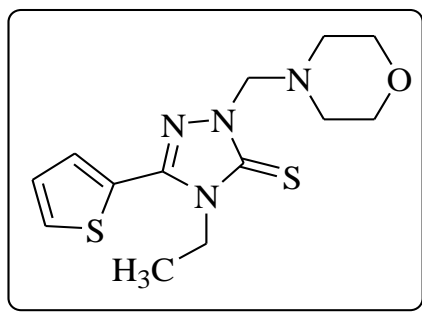

Kirsty L. Smitten et al [26] synthesized the Triazole-based Osmium (II) complexes displaying red/near-IR luminescence: antimicrobial activity and super-resolution imaging.

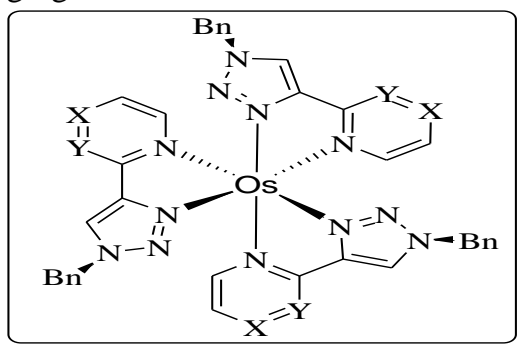

Xiangyi Jiang et al [27]have made Discovery of novel 1,4-disubstituted 1,2,3-triazole phenylalanine derivatives as HIV-1 capsid inhibitors.
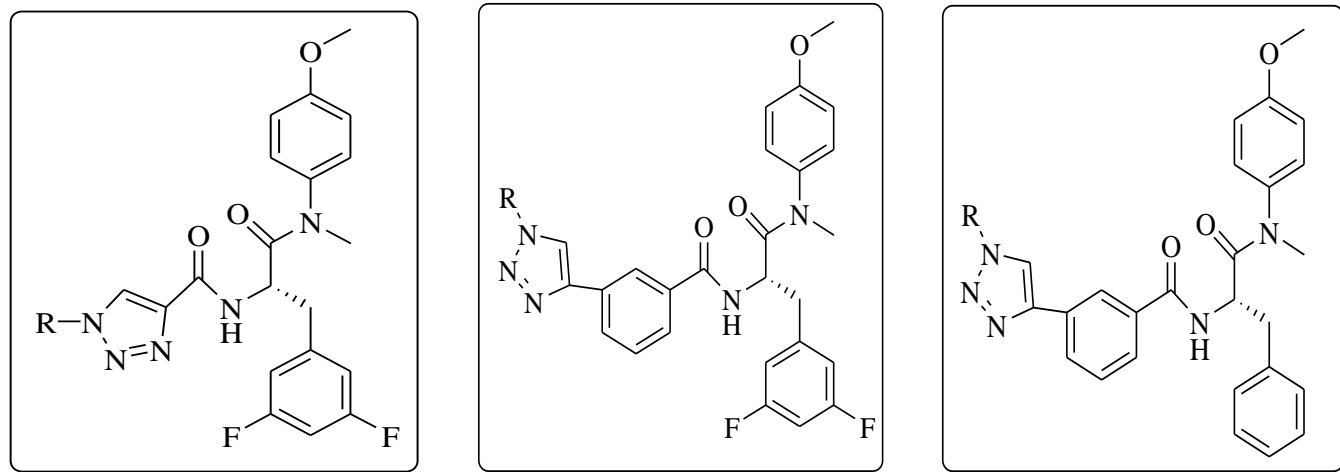


\section{International Journal of Current Science Research and Review}

ISSN: 2581-8341

Volume 05 Issue 01 January 2022

DOI: 10.47191/ijesrr/V5-i1-25, Impact Factor: 5.825

IJCSRR@ 2022

www.ijesrr.org

Gur Jaspreet Singh et al [28] Synthesis and characterization of microwave-assisted biologically active triazole silanes

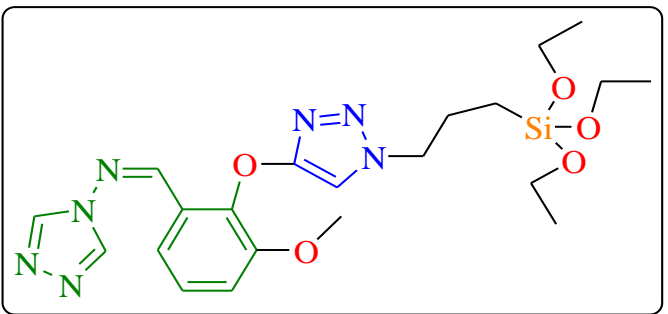

David D. N'Da et al [29] Synthesis and in vitro antimycobacterial and antileishmanial activities of hydroquinone-triazole hybrids.<smiles>[R]c1cn(-c2cc(O)ccc2O)nn1</smiles>

Iwona E. Głowacka et al [30] Synthesis and antimicrobial activity of novel 1,2,3-triazole-conjugates of quinazolin-4-ones.

Claire Simons et al [31] Design and Synthesis of Imidazole and Triazole Pyrazoles as Mycobacterium Tuberculosis CYP121A1 Inhibitors
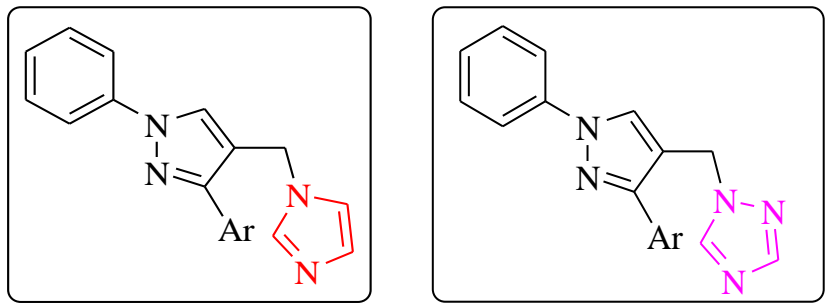

Sarbani Pal et al [32] Synthesis, biological evaluation, and docking study of a series of 1,4-disubstituted 1,2,3-triazole derivatives with an indole-triazole-peptide conjugate

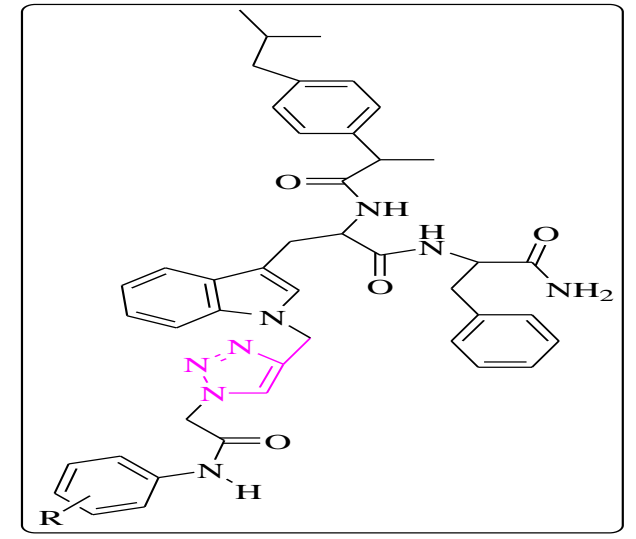

Zineb Khaldi et al [33] showed the Synthesis, characterization, and antibacterial activities of a new lignocellulosic material carrying aryl triazole moiety.

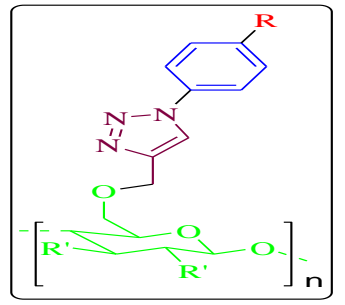




\section{International Journal of Current Science Research and Review}

ISSN: 2581-8341

Volume 05 Issue 01 January 2022

DOI: 10.47191/ijesrr/V5-i1-25, Impact Factor: 5.825

IJCSRR@ 2022

Www.ijesrr.org

Mohyeddin Assali et al [34] study the Synthesis, Biological Activity, and Molecular Modeling Studies of Pyrazole and Triazole Derivatives as Selective COX-2 Inhibitors.
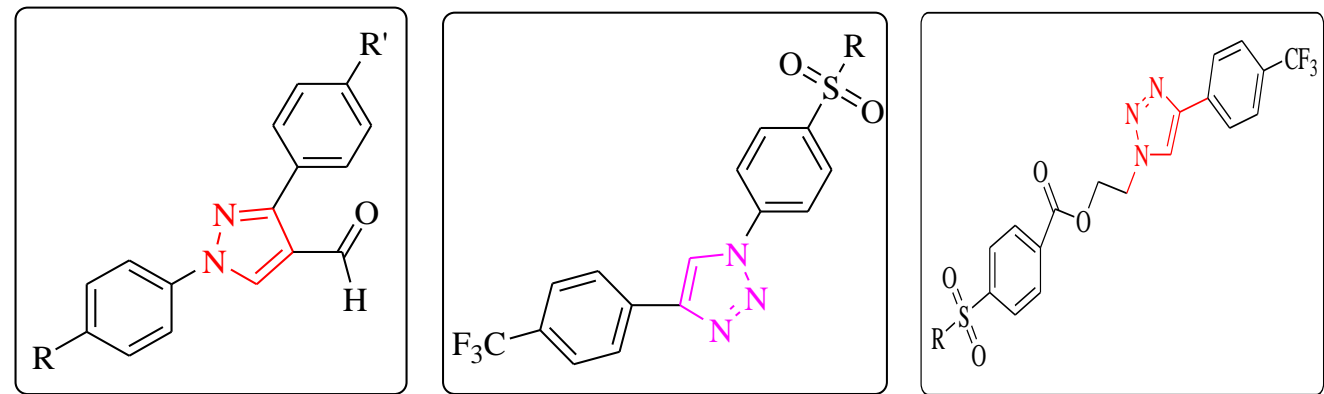

R. Ramesh Raju et al [35] have study the Design, Synthesis, and Anticancer Activity of 1,2,3-Triazole Linked 1,2-Isoxazoleimidazo[4,5-b] pyridine Derivatives

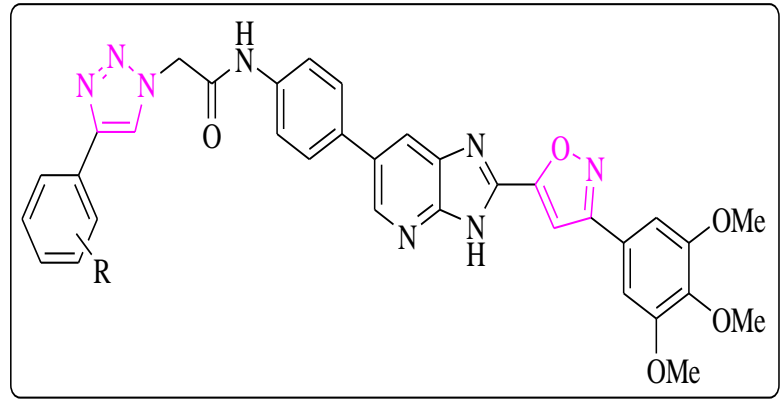

Fabrice Pagniez et al [36] Biological exploration of a novel 1,2,4-triazoleindole hybrid molecule as antifungal agent

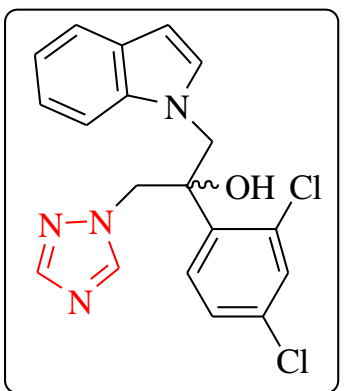

Adinarayana Nandikolla et al [37] reported the Synthesis, study of antileishmanial and antitrypanosomal activity of imidazo pyridine fused triazole analogues.

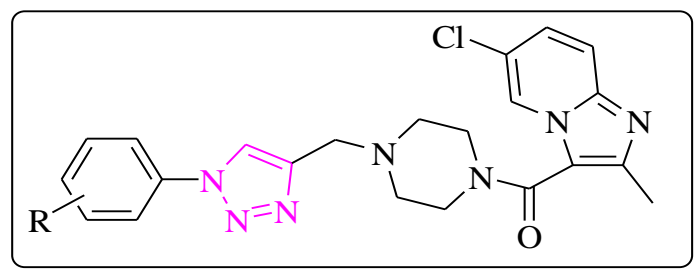

Raju Atcha et al [38] Design and Synthesis of Triazole Conjugated Novel 2,5-Diaryl Substituted1,3,4-Oxadiazoles as Potential Antimicrobial and Anti-fungal Agents.

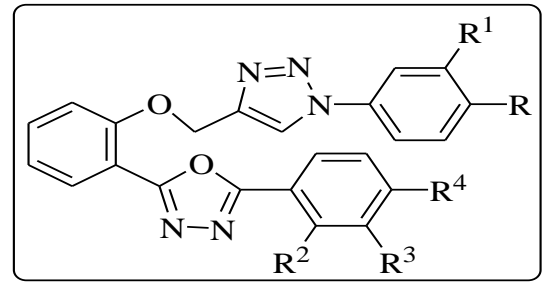




\section{International Journal of Current Science Research and Review}

ISSN: 2581-8341

Volume 05 Issue 01 January 2022

DOI: 10.47191/ijesrr/V5-i1-25, Impact Factor: 5.825

IJCSRR@ 2022

www.ijcsrr.org

Merve Gokalp et al [39]reported the Triazole based azo molecules as potential antibacterial agents: Synthesis, characterization, DFT, ADME and molecular docking studies
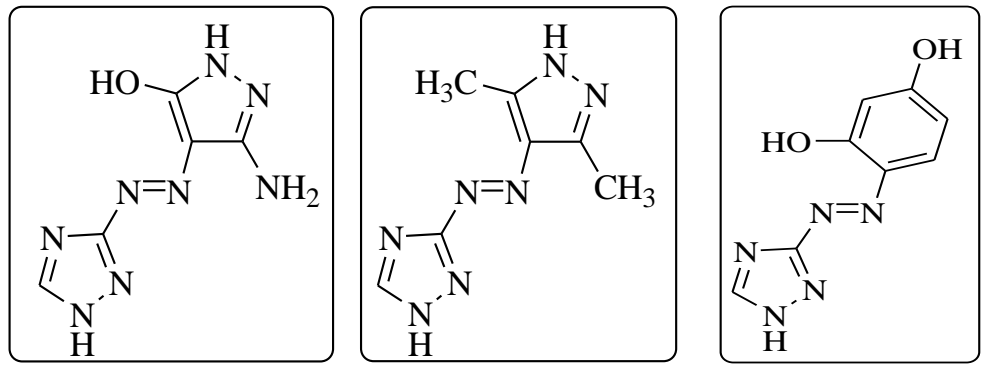

Artur M. S. Silva et al [40] have study A step-by-step synthesis of Triazole-Benzimidazole-Chalcone hybrids: Anticancer activity in human cells

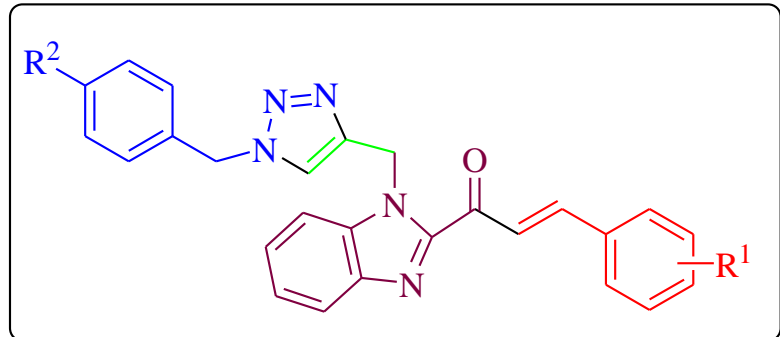

Ramesh Gondru et al [41] 1,2,3-triazole-thiazole hybrids: Synthesis, in vitro antimicrobial activity and antibiofilm studies.<smiles>[R]c1csc(NN=Cc2ccc(OCc3cn(-c4ccc(OC)cc4)nn3)cc2)n1</smiles>

Kishan P. Haval et al [42] report the Design and Synthesis of New Indanol-1,2,3-triazole Derivatives as Potent Antitubercular and Antimicrobial Agents

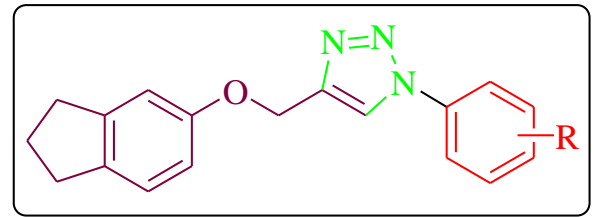

Fliur Macaev et al [43] New vinyl-1,2,4-triazole derivatives as antimicrobial agents: Synthesis, biological evaluation and molecular docking studies.

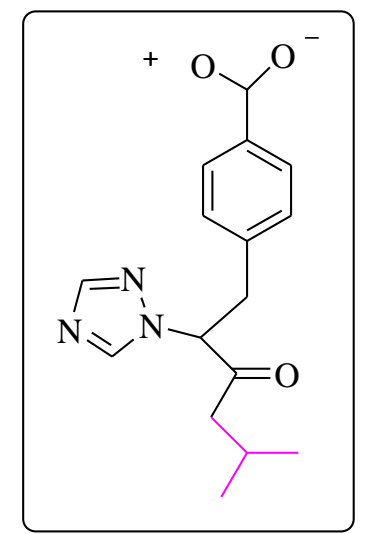




\section{International Journal of Current Science Research and Review}

ISSN: 2581-8341

Volume 05 Issue 01 January 2022

DOI: 10.47191/ijcsrr/V5-i1-25, Impact Factor: 5.825

IJCSRR@ 2022

Yaser Mahmoudi et al [44] the group of scientists have carried out the synthesis of New potent antifungal triazole alcohols containing N-benzylpiperazine carbodithioate moiety. Which shows in vitro evaluation and in silico study.

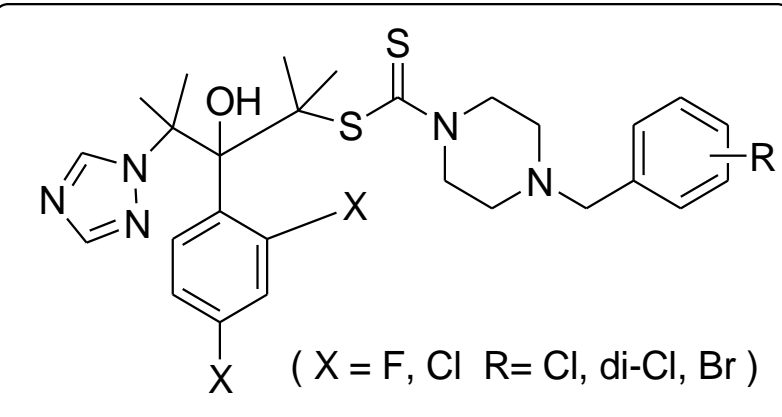

Deepti Goyal et al [45] they reported A novel series of triazole-based compounds have been designed, synthesised and evaluated as multi-target directed ligands (MTDLs) against Alzheimer disease.

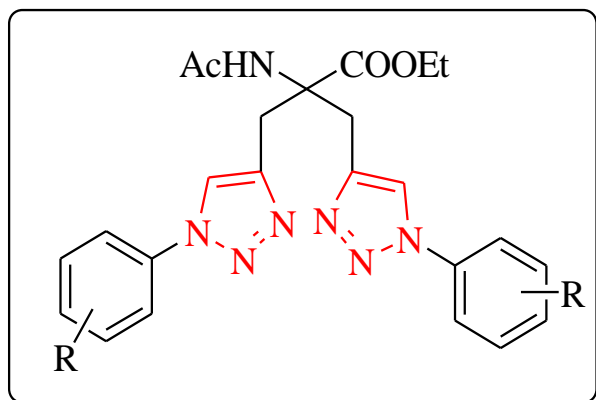

Elson A. Costa et al [46] have reported the study to design, synthesize and evaluate the potential analgesic and anti-inflammatory effects of 5-[1-(4-fluorphenyl)-1H-1,2,3-triazol-4-yl]-1H-tetrazole (LQFM-096: a new triazole compound) as well as to elucidate its possible mechanisms of action study and Mechanisms involved in the antinociceptive and anti-inflammatory effects of a new triazole derivative: 5-[1-(4-fluorophenyl)-1H-1, 2,3-triazol-4-yl]-1H-tetrazole (LQFM-096).<smiles>Fc1ccc(-n2cc(-c3nnn[nH]3)nn2)cc1</smiles>

Yitao Li et al [47] have synthesized effective fungicide Novel Triazole Sulphonamide derivatives containing a Benzylamine Moiety which is applicable in the plant effective against cucumber downy mildew. They study triazole sulphonamide which played a very important role in the field of research to new agrochemical compounds formulation.<smiles>[R11]CN(C1C2CC3CC1C32)S(=O)(=O)c1ncn(S(=O)(=O)N(C)C)n1</smiles> 


\section{International Journal of Current Science Research and Review}

ISSN: 2581-8341

Volume 05 Issue 01 January 2022

DOI: 10.47191/ijesrr/V5-i1-25, Impact Factor: 5.825

IJCSRR@ 2022

Www.ijesrr.org

\section{CONCLUSIONS}

From the above information, it can be said that 1,2, 4-triazole derivatives can be prepared using different methods like ring opening, rearrangement and substitution reaction. The biological profiles of these new derivatives of 1, 2, 4- triazole also reveal the therapeutic importance of it. An attempt of modify of the moiety will increase therapeutically uses of 1, 2, 4-triazole derivatives. These heterocyclic derivatives will result into introduction of therapeutically potent drugs. We must hope that further investigation gets carried on to find out more efficient derivatives of 1,2,4- triazole for such a disease whose treatment are challenging in the field of medical science.

\section{ACKNOWLEDGEMENTS}

The authors would like to thanks Principal MSG College Malegaon Dist. Nashik affiliated to Savitribai Phule Pune University, Pune, India for their guidance.

\section{REFERENCES}

1. Y Abboud, T Saffaj, A Chagraoui E Bouari,K Brouzi ,O Tanane, and B Ihssane, Biosynthesis, characterization and antimicrobial activity of copperoxide nanoparticles (CONPs) produced using brown alga extract (Bifurcaria bifurcata), Appl Nanosci, 2013, 4, 571-576.

2. S Sugirdha ,V Murugan, R Ravindran, T Paramasivan . Perumal,V Velkannan, and K Karthikeyan,Synthesis of 1,2,3Triazole Tethered 3- Hydroxy-2-oxindoles: Promising Corrosion Inhibitors for Steel in Acidic Medium and Their AntiMicrobial Evaluation, Chemistry Select 2020, 5, 2130 - 2134

3. Z Xuezhen ,LK Iris ,Wong, KF Chan, J Cui, MC Law, TC Chong,H Xuesen, MC Larry Chow and TH Chan, Triazole Bridged Flavonoid Dimers as Potent, Nontoxic, and Highly Selective Breast Cancer Resistance Protein (BCRP/ABCG2) Inhibitors J. Med. Chem. 2019, 62, 8578-8608

4. JW Zhao, Z Hui Wu, JW Guo, MJ Huang, YZ You, HM Liu, LH Huang Synthesis and anti-gastric cancer activity evaluation of novel triazole nucleobase analogues containing steroial/coumarin/quinoline moieties European Journal of Medicinal Chemistry, 2019, 181,111520

5. Z Zhang, L Kang, GY Zhang, YZ Tang, J Zhen, Design, synthesis and biological activities of novel pleuromutilin derivatives with a substituted triazole moiety as potent antibacterial Agents European Journal of Medicine Chemistry 2020,204, 112604

6. NH Zaher, MI Mostafa, AY Altaher Design, synthesis and molecular docking of novel triazole derivatives as potential CoV helicase inhibitors Acta Pharm. 2020,7, 145-159

7. P Yadav, JK Yadav, A Agarwal and SK Awasthi, Insights into the interaction of potent antimicrobial chalcone triazole analogs with human serum albumin:spectroscopy and molecular docking approaches ,RSC Adv., 2019, 9,31969

8. ND Thanh, DS Hai, VT Ngoc Bich, Pham TT Hien, NT Ky Duyen NT Mai, TT Dung, VT Ngoc, HT Kim Van, LH Dang, DN Toan, TT Thanh Van, Efficient click chemistry towards novel 1H 1,2,3-triazole-tethered 4H- chromene Dglucose conjugates: Design, synthesis and evaluation of in vitro antibacterial, MRSA and antifungal activities European Journal of Medicinal Chemistry 2019,167, 454e471.

9. S Sampath, M Vadivelu, R Ravindran, PT Perumal, V Velkannan, and K Karthikeyan, Synthesis of 1,2,3-Triazole Tethered 3-Hydroxy-2-oxindoles Promising Corrosion Inhibitors for Steel in Acidic Medium and Their Anti-Microbial Evaluation. Chemistry Select 2020, 5, $2130-2134$.

10. NS Gouda, V Pooladanda, KM Chandra, PS Lakshmi Soukyaa, R Alvalad, P Kumarb, C Nagarajb RD Bharathb, IA Qureshie, C Goduguc, M Alvala, Novel benzimidazole-triazole hybrids as apoptosis inducing agents in lung cancer: Design, synthesis, 18F-radiolabeling \& galectin-1 inhibition studies. Bioorganic Chemistry ,2020,102, 104125

11. KS Raju, SA Reddy, G Sabithaa, VS Krishna, D Sriram, KB Reddy, SR Sagurthi. Synthesis and biological evaluation of 1H-pyrrolo[2,3-d]pyrimidine-1,2,3-triazole derivatives as novel anti-tubercular agents. Bioorganic \& Medicinal Chemistry Letters ,2019,29, 284-290. 


\section{International Journal of Current Science Research and Review}

ISSN: 2581-8341

Volume 05 Issue 01 January 2022

DOI: 10.47191/ijesrr/V5-i1-25, Impact Factor: 5.825

IJCSRR@ 2022

Www.ijcsrr.org

12. A Rastegari, H Nadri, M Mahdavi, A Moradi, SS Mirfazli, N Edraki, FH Moghadam, B Larijanic, T Akbarzadeha, M Saeedi, Design, synthesis and anti-Alzheimer's activity of novel 1,2,3- triazolechromenone carboxamide derivatives Bioorganic Chemistry ,2019,83 391-401.

13. J Ramprasad, VK Sthalama, RL Murthy Thampunuri, S Bhukya, R Ummanni, S Balasubramanian, S Pabbaraja. Synthesis and ealuation of a novel quinoline-triazole analogs for antitubercular properties via molecular hybridization approach, Bioorganic \& Medicinal Chemistry Letters 2019, 29, 126671.

14. M Rajabi, K Godugu, T Sudha, DJ Bharali, and SA Mousa. Triazole Modified Tetraiodothyroacetic Acid Conjugated to Polyethylene Glycol: High Affinity Thyrointegrin $\alpha v \beta 3$ Antagonist with Potent Anticancer Activities in Glioblastoma Multiforme. Bioconjugate Chem. 2019, 30, 3087-3097.

15. M Thayane. Queiroz, V Erika M Orozco, RV Silva, S L Santos, BP Milena Soares, DP Bezerra, Andre LM Porto. Semisynthesis of $\beta$-keto-1,2,3-triazole derivatives from ethinylestradiol and evaluation of the cytotoxic activity Heliyon ,2019,5, e02408, 1-6.

16. RR Pillai, K Karrouchi, S Fettach, S Armaković, SJ Armaković, Y Brik, J Taoufik, S Radi, ME Abbes FM Ansar. Synthesis, spectroscopic characterization, reactive properties by DFT calculations, molecular dynamics simulations and biological evaluation of schiff bases tethered 1,2,4-triazole and pyrazole rings. Journal of Molecular Structure 2860 18 31119-0.

17. Z Najafia, M Mahdavi, M Saeedid, E K Razkenari, N Edraki,S Mohammad, M Khanavih, T Akbarzadeh Novel tacrinecoumarin hybrids linked to 1,2,3-triazole as anti-Alzheimer's compounds: In vitro and in vivo biological evaluation and docking study Bioorganic Chemistry 2019, 303-316.

18. M Muhamad, S Anwar, F Elgamal, ER. Ahmed, M Omar Aly Potent mbretastatin A-4 analogs containing 1,2,4-triazole: Synthesis, antiproliferative, anti-tubulin activity, and docking study European Journal of Medicinal Chemistry 2019, 183, 111697.

19. AI Matesanz, J Herrero, EJ Faraco, L Cubo, and AG Quiroga. New PtII triazol thiosemicarbazone'complexes. Analysis of their reactivity and Potential antitumoral action, Chem Bio Chem.

20. G Lu, Xin-yang Li, K Mohamed, D Wang, F Meng. Design, synthesis and biological evaluation of novel uracil derivatives bearing 1, 2, 3-triazole moiety as thymidylate synthase (TS) inhibitors and as potential antitumor drugs. European Journal of Medicinal Chemistry 2019,171, 282e296.

21. L Shuai, Xin-yang Li, TJ Zhang, J Zhu, WH Xue, XH Qian, F Meng.Design, synthesis and biological evaluation of erythrina derivatives bearing a 1,2,3-triazole moiety as PARP-1 inhibitors Bioorganic Chemistry 2020,96103575.

22. L Kashmiri , N Poonia, P Rani, A Kumar, A Kumar. Design, synthesis, antimicrobial evaluation and docking studies of urea-triazole-amide hybrids. Journal of Molecular Structure 1215 ,2020 128234: 1-11.

23. A Kaur, SS Narang, A Kaur, M Sukhmani , N Priyadarshi, B Goyal, NK Singhal and D Goyal, Multifunctional MonoTriazole Derivatives Inhibit A $\beta 42$ Aggregation and $\mathrm{Cu} 2+-$ Mediated A $\beta 42$ Aggregation and Protect Against A $\beta 42-$ Induced Cytotoxicity Chem. Res. Toxicol. 2019, 32, 1824-1839

24. O Grytsaia, O Valiashkoa, MP Campillo, M Dufies, A Hagege, L Demangea, S Martial, G Pagesb, C Ronco, R Benhida. Synthesis and biological evaluation of 3-amino-1,2,4-triazole derivatives as potential anticancer compounds Bioorganic Chemistry 2020,104, 104271, 1-10.

25. Timur, ÜM Kocyigit, T Dastan, S Sandal, AO Ceribası, P Taslimi, İ Gulcin, M Koparir, M Karatepe, C Mehmet . In vitro cytotoxic and in vivo antitumoral activities of some aminomethyl derivatives of 2,4-dihydro-3H-1,2,4-triazole-3-thionesEvaluation of their acetylcholinesterase and carbonic anhydrase enzymes inhibition profiles J Biochem Mol Toxicol.2018; e22239, 1-14.

26. LK Smitten, A Paul ,Scattergood, C Kiker, A Jim A Thomas and IP Elliott. Triazole-based osmium (II) complexes displaying red/near-IR luminescence: antimicrobial activity and super-resolution imaging. Chem. Sci., 2020, 11, 89288935.

27. J Xiangyi ,W Gaochan, AW Zalloum, ME Meuser, A Dick, Lin Sun, CH Chen, D Kang, L Jing, R Jia, S Cocklin, KH Lee, Xinyong Liu and P Zhan. Discovery of novel 1,4-disubstituted 1,2,3-triazole phenylalanine derivatives as HIV-1 capsid inhibitors. RSC Adv., 2019, 9, 28961-28986 


\section{International Journal of Current Science Research and Review}

ISSN: 2581-8341

Volume 05 Issue 01 January 2022

DOI: 10.47191/ijesrr/V5-i1-25, Impact Factor: 5.825

IJCSRR@ 2022

Www.ijcsrr.org

28. G Singh, P Satija, A Singh, Sanchita, Darpandeep AW Mario,CE Ruiz, MA Esteban, S Sinha, R Sehgal. Synthesis and characterization of microwave-assisted biologically active triazole silanes Appl Organometal Chem. 2019; e4695. 1-15.

29. CM Horn, J Aucamp, FJ Smit, R Seldon, A Jordaan, Digby F Warner, D David . Synthesis and in vitro antimycobacterial and antileishmanial activities of hydroquinone-triazole hybrids Medicinal Chemistry Research 2020, 1-13.

30. IE Głowacka, P Gronkowski, P Lisiecki, Ł Kalinowski, DG Piotrowski,Synthesis and antimicrobial activity of novel 1,2,3-triazole-conjugates of quinazolin-4-ones Arch Pharm Chem Life Sci. 2019; e1800302.

31. SM. Kishk, KJ McLean, S Sood, D Smith, WD Jack .Evans, A Mohamed Helal, SG Mohamed, I. Salama, MS Mostafa, L Pedro S. de Carvalho, CW Levy, AW Munro, and C Simons. Design and Synthesis of Imidazole and Triazole Pyrazoles as Mycobacterium Tuberculosis CYP121A1 Inhibitors Chemistry Open 2019, 8, 995-1011

32. S Suryapeta, N Papigani, V Banothu, PK Dubey, K Mukkanti, S Pal. Synthesis, biological evaluation, and docking studybof a series of 1,4-disubstituted 1,2,3-triazole derivatives with an indole-triazole-peptide conjugate. J Heterocyclic Chem. 2020;1-16.

33. Z Khaldi, C Besse, J Kerim NT Keki, TS Ouk, V Gloaguen, R Zerrouki, Synthesis, Spectroscopic Characterization, Molecular Docking, and Evaluation of Antibacterial Potential of Transition Metal Complexes Obtained Using Triazole Chelating Ligand Hindawi Polym Adv Technol. 2018;1-7

34. M Assali, M Abualhasan, H Sawaftah,H Mohammed and A Mousa. Synthesis, characterization, and antibacterial activities of a new lignocellulosic material carrying aryl triazole moiety Journal of Chemistry Volume 2020,1-14.

35. IS Murthya, R Sreenivasulub, G Alluraiahc, and RR Raju Russian Design, Synthesis, and Anticancer Activity of 1,2,3Triazole Linked 1,2-Isoxazole-imidazo[4,5-b] pyridine Derivatives.Journal of General Chemistry, 2019, Vol. 89, No. 8, pp. 1718-1723.

36. Pagniez, L Nicolas, MN Young, OG Isabelle, C Picot, M Le Borgne \& P Le Pape, Biological exploration of a novel 1,2,4triazoleindole hybrid molecule as antifungal agent Journal of Enzyme Inhibition and Medicinal Chemistry 2020, Vol. 35, No. 1, 398-403.

37. AN Nandikolla, S Srinivasarao, B Karan Kumar, S Narayanan Murugesan, H Aggarwal, Louise L. Major, TK. Smithc and K Venkata Gowri Chandra Sekhar, Synthesis, study of antileishmanial and antitrypanosomal activity of imidazo pyridine fused triazole analogues, RSC Adv., 2020, 10, 38328-38343.

38. S Bitlaa, SR Sagurthib, R Dhanavatha, PM Reddya,S Birudarajua, AA Gayatrib, BV Kumara, K Raju Atcha,,Journal of Molecular Structure 2020: 1-36 M G€okalp, B Dede, T Tilki, ÇK Atay, Triazole based azo molecules as potential antibacterial agents: Synthesis, characterization, DFT, ADME and molecular docking studies Journal of Molecular Structure 2020,1212 128140

39. A Djemoui, A Naouri, RO Mohammed, DD Souli Lahecen, Mokhtar Boualem Lahrech, Leila Boukenna, Hélio M. T. Albuquerque, Liza Saher, Djenisa H. A. Rocha, Fátima Liliana Monteiro, Luísa A. Helguero, Khaldoun Bachari, Oualid Talhi, and Artur M. S. A step-by-step synthesis of Triazole-Benzimidazole-Chalcone hybrids: Anticancer activity in human cells, Silva, 2019, 1-19.

40. R Gondru, S Kanugala, S Raj, GC Kumar, M Pasupuleti, J Banothu, R Bavantula, 1,2,3-triazole- thiazole hybrids: Synthesis, in vitro antimicrobial activity and antibiofilm studies, Bioorganic \& Medicinal Chemistry Letters 2020, 1-20.

41. PS Phataka, RD Bakalea, RS Kulkarnia, ST Dhumalb, PP Dixitc, VS Krishnad, D Sriramd, VM. Khedkare, and KP. Haval, Design and Synthesis of New Indanol-1,2,3-triazole Derivatives as Potent Antitubercular and Antimicrobial Agents, 2020, $1-16$.

42. E Stingaci, M Zveaghintev, S Pogrebnoi, L Lupascu, V Valica, L Uncu, A Smetanscaia, M Drumea, A Petrou, A Ciric, J Glamoclija, M Sokovic, V Kravtsov, A Geronikaki, F Macaev, New vinyl-1,2,4-triazole derivatives as antimicrobial agents: Synthesis, biological evaluation and molecular docking studies, Bioorganic \& Medicinal Chemistry Letters 2020.

43. Y Mahmoudi, H Badali, SM Hashemi, M Ansari, H Fakhim M Fallah, S Mohammad, E Saeed, New potent antifungal triazole alcohols containing N-benzylpiperazine carbodithioate moiety: Synthesis, in vitro evaluation and in silico study, Bioorganic Chemistry 2019,90 103060, 1- 10.

44. A Kaur, S Mann, A Kaur, N Priyadarshi, B Goyal, NK Singhal, D Goyal, Multi-target-directed triazole derivatives as promising agents for the treatment of Alzheimer's disease,Bioorganic Chemistry 2019, 87 572-584. 


\section{International Journal of Current Science Research and Review}

ISSN: 2581-8341

Volume 05 Issue 01 January 2022

DOI: 10.47191/ijcsrr/V5-i1-25, Impact Factor: 5.825

IJCSRR@ 2022

www.ijcsrr.org

45. CS Cardoso, PB Daiany Silva, DM. Silva, FI Florentino, JO. Fajemiroy, KS Lorrane JP Moreir, Vasconcelos, Germán Sanz,G Boniek, LM. Lião, DS. Lima, CA Fernanda dos Santos, R Menegatti,A Elson ,Costa, Mechanisms involved in the antinociceptive and anti-inflammatory effects of a new triazole derivative:5-[1-(4-fluorophenyl)-1H-1,2,3-triazol -4-yl]-1H-tetrazole (LQFM-096),Inflammo pharmacology 2020, 1-20.

46. Y Li, Wenqiang Yao, JL, Falin Li, Yang Wu, and Junxing Xu, Design, Synthesis, and Biological Activity of Novel Triazole Sulfonamide Derivatives Containing a Benzylamine Moiety J. Heterocyclic Chem., 2019,00 1-7

Cite this Article: Kuldeep T. Padhyar, Rajendra S. Patil, Navanand B. Wadwale (2022). A brief review on Triazole and its Pharmacological Applicatio. International Journal of Current Science Research and Review, 5(1), 212-225 